\title{
Development of $\mathrm{CD}^{+} \mathrm{T}$ cells expressing a nominally MHC class I-restricted $T$ cell receptor by two different mechanisms
}

\author{
Qing Ge, Phillip D. Holler, Vinay S. Mahajan, Tam Nuygen, Herman N. Eisen*, and Jianzhu Chen* \\ Center for Cancer Research and Department of Biology, Massachusetts Institute of Technology, Cambridge, MA 02139 \\ Contributed by Herman N. Eisen, December 8, 2005
}

Differences in T cell receptor (TCR) signaling initiated by interactions among TCRs, coreceptors, and self-peptide-MHC complexes determine the outcome of CD4 versus CD8 lineage of $T$ cell differentiation. The $\mathrm{H}-2 \mathrm{~L}^{\mathrm{d}}$ and $\mathrm{K}^{\mathrm{bm} 3}$ alloreactive $2 \mathrm{CTCR}$ is positively selected by $\mathrm{MHC}$ class I $\mathrm{K}^{\mathrm{b}}$ and a yet-to-be identified nonclassical class I molecule to differentiate into $\mathrm{CD}^{+} \mathrm{T}$ cells. Here we describe two mechanisms by which $\mathrm{CD}^{+}{ }^{+} 2 \mathrm{C}$ T cells can be generated in $2 \mathrm{C}$ TCR-transgenic mice. In the RAG ${ }^{-/-}$background, development of $\mathrm{CD}^{+}{ }^{+} \mathrm{2C}$ T cells requires the expression of both I-A ${ }^{\mathrm{b}}$ and the TAP genes, indicating that both MHC class I and II molecules are required for positive selection of these $\mathrm{T}$ cells. Notably, only some of the $2 \mathrm{C}^{+} \mathrm{RAG}^{-1-}$ mice $(\approx 30 \%)$ develop $\mathrm{CD}^{+}{ }^{+} \mathbf{2 C} \mathrm{T}$ cells, with frequencies in individual mice varying from $0.5 \%$ to as high as $\approx \mathbf{5 0} \%$. In the RAG ${ }^{+}$background, where endogenous TCR $\alpha$ genes are rearranged and expressed, $\mathrm{CD}^{+} 2 \mathrm{C} \mathrm{T}$ cells are generated because these cells express the 2 C TCR as well as additional TCRs, consisting of the 2 C TCR $\beta$ and endogenous TCR $\alpha$ chains. Similarly, T cells expressing the OT- 1 TCR, which is nominally MHC class I-restricted, can also develop into $\mathrm{CD}^{+}{ }^{+} \mathrm{T}$ cells through the same two mechanisms. Thus, expression of two TCRs by a single thymocyte, TCR recognition of multiple MHC molecules, and heterogeneity of TCR, coreceptors, and peptide-MHC interactions in the thymus all contribute to the outcome of CD4 versus CD8 lineage development.

coreceptors | lineage differentiation | antigen recognition | degeneracy

$\mathbf{T}_{\mathrm{T}}^{\mathrm{h}}$ he antigens recognized by $\alpha \beta$ T cell receptors (TCR) are MHC class I and class II molecules in association with peptides (1-3). Most $\alpha \beta$ T cells belong to one of the two lineages defined by the mutually exclusive expression of CD8 or CD4 coreceptors, which bind MHC class I and class II molecules, respectively. Because the binding of the coreceptors to MHC molecules stabilizes weak interactions between TCRs and peptide-MHC (pMHC) complexes, $\mathrm{CD}^{+} \mathrm{T}$ cells are $\mathrm{MHC}$ class I-restricted whereas $\mathrm{CD}^{+} \mathrm{T}$ cells are MHC class II-restricted. The concordance of CD4 or CD8 lineage development with specificity for class I or II MHC is established during differentiation of $\mathrm{CD}^{+}{ }^{+} \mathrm{CD}^{+}$double-positive (DP) thymocytes in the thymus by a process referred to as positive selection (4). Whether a DP thymocyte differentiates into a CD4 ${ }^{+}$ or $\mathrm{CD}^{+} \mathrm{T}$ cell depends on differences in TCR signaling as a result of interactions among TCR, coreceptors, and self-peptide-MHC (self-pMHC) complexes (5-8).

Many TCRs are known to interact not only with self- but also with foreign MHC molecules (alloreactivity). Among the bestdocumented examples is the recognition of different pMHC complexes by a TCR called $2 \mathrm{C}(9)$. The $2 \mathrm{C}$ TCR was derived from a $\mathrm{CD}^{+}$cytotoxic $\mathrm{T}$ lymphocyte (CTL) clone from an $\mathrm{H}-2^{\mathrm{b}}$ mouse (BALB.B) that was injected with $\mathrm{H}-2^{\mathrm{d}}$ cells $(10,11)$. The $2 \mathrm{C}$ TCR reacts with $\mathrm{L}^{\mathrm{d}}$ in association with two overlapping peptides QLSPFPFDL (QL9) and p2Ca derived from $\alpha$-ketoglutarate dehydrogenase $(10,12,13)$. The $2 \mathrm{C}$ TCR is also alloreactive to $\mathrm{K}^{\mathrm{bm} 3}$ in association with the dEV8 peptide derived from NADHubiquinone oxoreductase $(14,15)$. By constructing transgenic mice expressing the $2 \mathrm{C}$ TCR and crossing the TCR transgene onto

different $\mathrm{H}-2$ backgrounds, it was shown that the positive selecting $\mathrm{MHC}$ for the $2 \mathrm{C}$ T cells is $\mathrm{K}^{\mathrm{b}}(16,17)$. Among the naturally derived peptides recognized by the $2 \mathrm{CTCR}$ in association with $\mathrm{L}^{\mathrm{d}}$ and $\mathrm{K}^{\mathrm{bm} 3}$, p2Ca and dEV8 bind weakly to $\mathrm{K}^{\mathrm{b}}$ and behave as weak agonists (18). However, several strong agonist peptides have been identified in combinatorial libraries to associate with $\mathrm{K}^{\mathrm{b}}$ and activate the $2 \mathrm{C}$ T cells (19). Among them, SIYRYYGL (SIY) has been extensively characterized. In addition to recognizing various peptides in association with MHC class $\mathrm{I} \mathrm{L}^{\mathrm{d}}, \mathrm{K}^{\mathrm{bm} 3}$, and $\mathrm{K}^{\mathrm{b}}$ molecules, the $2 \mathrm{C}$ TCR was also shown recently to recognize a nonclassical class I molecule, leading to differentiation of $\mathrm{CD} 8^{+} \mathrm{T}$ cells that home to the intestine during fetal and neonatal development (20).

The ability of a given TCR to interact with multiple MHC molecules, especially both class I and class II, can have a significant influence on the development of CD4 versus CD8 T cells. For example, the HY TCR nominally recognizes class $\mathrm{I}^{\mathrm{b}}$ for CD8 $\mathrm{T}$ cell development but also interacts with class II I-A ${ }^{\mathrm{b}}$ for CD4 T cell development (21). Similarly, the HA and AND TCRs nominally interact with class II MHC for CD4 T cell development but also promote the development of CD8 T cells on either the $\mathrm{RAG}^{-/-}$or the CD $4^{-1-}$ plus TCR $\alpha^{-1-}$ background $(22,23)$. The development of CD8 HA or AND transgenic T cells was shown to require the interaction of the TCRs with both class I and class II MHC molecules.

Further complicating CD4 and CD8 lineage differentiation is the possibility that a given $\mathrm{T}$ cell expresses two different TCRs. Although allelic exclusion at the TCR $\beta$ locus is stringently enforced at the DNA rearrangement level, there is no apparent allelic exclusion during the TCR $\alpha$ rearrangement (24-26). Some T cell lines have been shown to possess two functional TCR $\alpha$ rearrangements but to express only one TCR $\alpha$ polypeptide, indicating TCR $\alpha$ allelic exclusion at the transcription and/or posttranscription levels (27-29). However, $\approx 20 \%$ of T cells in humans and $10 \%$ of T cells in mice are estimated to express two TCR $\alpha$ chains, resulting in a significant fraction of T cells that express two TCRs (30). When two TCR transgenes are introduced into the same mouse, individual T cells from the resulting transgenic mice can express two different TCRs, as in mice expressing the OT-1 and P14 TCRs (31) or AND and 3A9 TCRs (32). Because DP thymocytes that express two TCRs are likely to recognize additional self-pMHC complexes, the presence of two TCRs could significantly affect CD4 versus CD8 lineage development. However, how the interactions of a single TCR with multiple MHC molecules and how multiple TCRs expressed by the same developing thymocyte affect CD4 versus CD8 lineage differentiation in the thymus have been examined to only a limited extent.

Conflict of interest statement: No conflicts declared.

Abbreviations: TCR, T cell receptor; DP, double-positive; CTL, cytotoxic T lymphocyte; SIY, SIYRYYGL; QL9, QLSPFPFDL; E:T ratio, effector-to-target cell ratio; PBMC, peripheral blood mononuclear cell.

*To whom correspondence may be addressed. E-mail: hneisen@mit.edu or jchen@mit.edu.

() 2006 by The National Academy of Sciences of the USA 

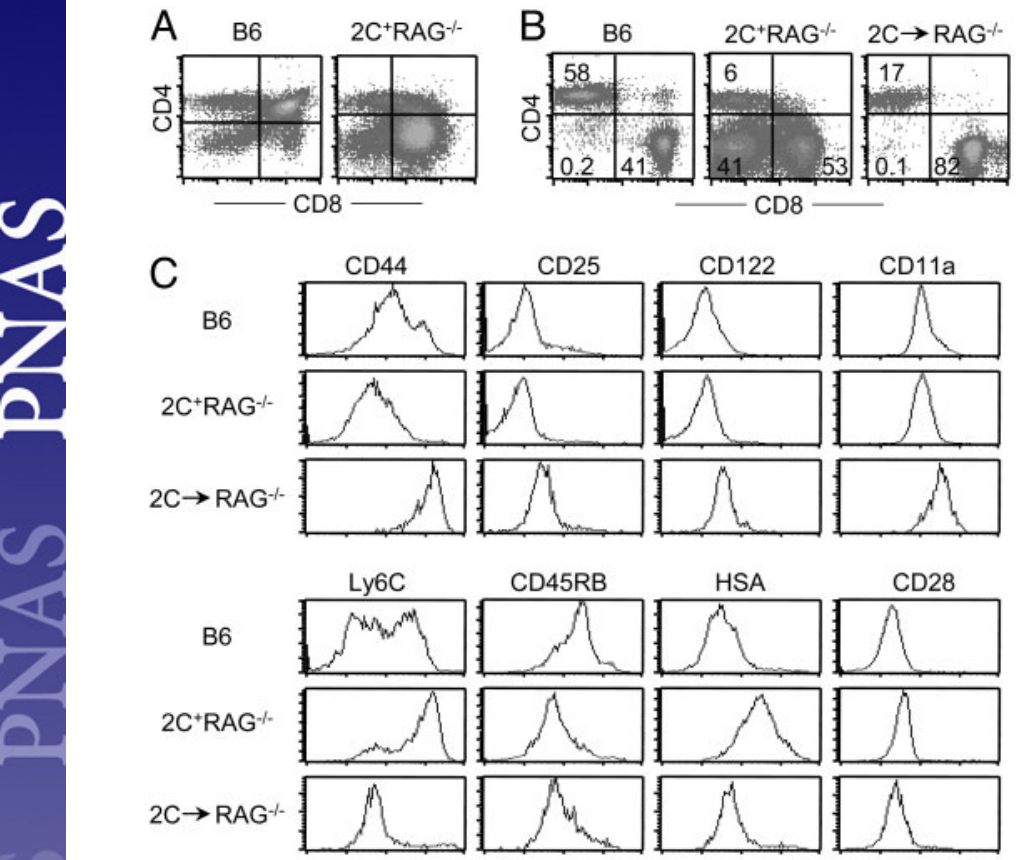

Fig. 1. Generation of mature $\mathrm{CD}^{+} 2 \mathrm{C}$ T cells in $2 \mathrm{C}^{+} \mathrm{RAG}^{-1-}$ mice. $(A)$ Comparison of CD4 versus CD8 staining profiles of thymocytes from a $B 6$ and a $2 \mathrm{C}^{+} \mathrm{RAG}^{-1-}$ mouse. (B) Presence of mature $\mathrm{CD}^{+}{ }^{+} \mathrm{C} \mathrm{C}$ cells in the lymph nodes of $2 \mathrm{C}^{+} \mathrm{RAG}^{-1-}$ mice. Lymph node cells from $\mathrm{B} 6$ mice, $2 \mathrm{C}^{+} \mathrm{RAG}^{-1-}$ mice, and $\mathrm{RAG}^{-1-}$ mice that had been adoptively transferred 2 months previously with naïve $2 \mathrm{C}$ T cells from $2 \mathrm{C}^{+} \mathrm{RAG}^{-1-}$ mice were stained with antibodies specific for the 2 C TCR (or for TCR $\beta$ for B6 mice), CD4, CD8 plus CD44, CD25, CD122, CD11a, Ly6C, CD45RB, HSA, or CD28. The two-dimensional dot plots show CD4 versus $\mathrm{CD} 8$ expression by $2 \mathrm{C}^{+}$cells (or $\mathrm{TCR} \beta^{+}$cells for $\mathrm{B} 6$ mice). The numbers indicate percentages of cells in the specific quadrant. (C) Comparison of selected surface markers among $\mathrm{CD}^{+}{ }^{+} \mathrm{T}$ cells from $\mathrm{B} 6$ mice, $2 \mathrm{C}^{+} \mathrm{RAG}^{-1-}$ mice, and $\mathrm{RAG}^{-1-}$ mice that had been adoptively transferred with naïve $2 \mathrm{C} \mathrm{T}$ cells. Continued from $B$, histograms show expression profiles of indicated markers by $\mathrm{CD}^{+}{ }^{+} \mathrm{C}^{+} \mathrm{T}$ cells or $\mathrm{CD} 4^{+} \mathrm{TCR} \beta^{+} \mathrm{T}$ cells (for $\mathrm{B} 6$ mice).

In our studies of $\mathrm{CD}^{+} \mathrm{T}$ cells expressing the $2 \mathrm{CTCR}$, we noticed that a high percentage of $2 \mathrm{C}$ TCR-transgenic mice harbor $2 \mathrm{C}^{+} \mathrm{T}$ cells that are $\mathrm{CD}^{+}\left(\mathrm{CD}^{-}\right)$, occasionally as many as $25-50 \%$ of total $2 \mathrm{C}$ T cells in spleen and lymph nodes. Here we show that these $\mathrm{CD}^{+}{ }^{2} \mathrm{C} \mathrm{T}$ cells are generated through two different mechanisms. In the $\mathrm{RAG}^{-1-}$ background, the $\mathrm{CD}^{+}{ }^{+} 2 \mathrm{C} \mathrm{T}$ cells are generated because they are positively selected by means of the $2 \mathrm{C}$ TCR by class II I-A $\mathrm{A}^{\mathrm{b}}$ as well as class $\mathrm{I} \mathrm{K}^{\mathrm{b}}$ molecules. In the $\mathrm{RAG}^{+}$ background, $\mathrm{CD}^{+}{ }^{+} \mathrm{C} \mathrm{T}$ cells are generated because the $\mathrm{T}$ cells express other TCRs in addition to the 2C TCR. The findings demonstrate that the $2 \mathrm{C}$ TCR recognizes peptides in association with not only the class $\mathrm{I} \mathrm{L}^{\mathrm{d}}, \mathrm{K}^{\mathrm{bm} 3}$, and $\mathrm{K}^{\mathrm{b}}$ and a yet-to-be identified nonclassical class I molecule but also the class II I-A ${ }^{\mathrm{b}}$ molecule. Our findings also show that the expression of two TCRs in a cell, TCR recognition of multiple $\mathrm{MHC}$ molecules, and the nonuniformity of TCR interactions with coreceptors and pMHC complexes in the thymus all contribute to the outcome of CD4 versus CD8 lineage development.

\section{Results}

Development of $\mathbf{C D}^{+} \mathbf{2} \mathbf{C}$ T Cells in $\mathbf{2 C ^ { + }} \mathbf{R A G}^{-1-}$ Mice. In adult mice, $\mathrm{CD}^{+} \mathrm{T}$ cells that express the $2 \mathrm{C}$ TCR are positively selected by the $\mathrm{K}^{\mathrm{b}}$ molecule. Consistently, in 2C TCR-transgenic mice on the $\mathrm{H}-2^{\mathrm{b}}$ (B6) and $\mathrm{RAG}^{-1-}$ backgrounds (referred to as $2 \mathrm{C}^{+} \mathrm{RAG}^{-1-}$ mice), $\mathrm{T}$ cell development in the thymus is biased toward the CD8 lineage and most of the $\mathrm{T}$ cells in the periphery are $\mathrm{CD}^{+}$(Fig. 1 $A$ and $B$ ). Although a substantial fraction of $2 \mathrm{C} \mathrm{T}$ cells in spleen and lymph nodes were $\mathrm{CD}^{-} \mathrm{CD}^{-}, \approx 30 \%$ of the $2 \mathrm{C}^{+} \mathrm{RAG}^{-1-}$ mice
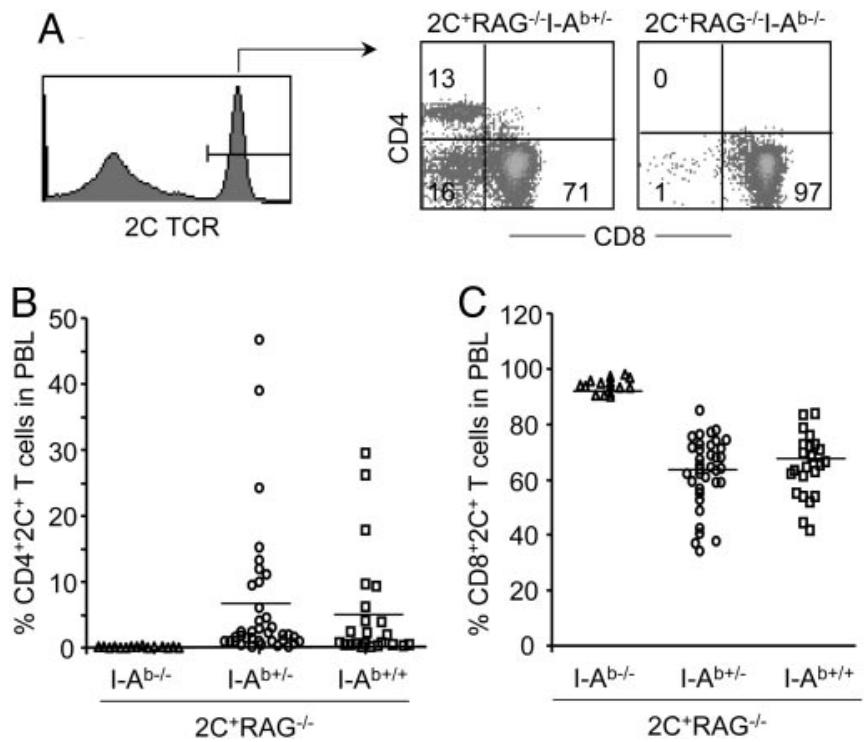

Fig. 2. Development of $\mathrm{CD}^{+} 2 \mathrm{CT}$ cells in $2 \mathrm{C}^{+} \mathrm{RAG}^{-1-}$ mice requires $\mathrm{MHC}$ class II I-A ${ }^{b}$. PBMC from $2 C^{+} R^{2} G^{-l-}-A^{b+l+}, 2 C^{+} R^{b} G^{-l-}-A^{b+l-}$, and $2 C^{+} R^{b} G^{-l-I-}$ $A^{b-1-}$ mice were analyzed for $2 C T C R, C D 4$, and CD8 expression. $(A) A$ representative histogram showing $2 \mathrm{CTCR}$ expression by all PBMC and dot plots showing $C D 4$ versus $C D 8$ expression gating on $2 \mathrm{C}^{+} \mathrm{T}$ cells for representative $2 \mathrm{C}^{+} \mathrm{RAG}^{-1-} \mathrm{I}-\mathrm{A}^{\mathrm{b}+1-}$ and $2 \mathrm{C}^{+} \mathrm{RAG}^{-1-} \mathrm{I}-\mathrm{A}^{\mathrm{b}-1-}$ mice. The numbers indicate percentages of cells in each quadrant. ( $B$ and $C$ ) Percentages of $C D 4^{+} 2 C^{+}$T cells and $\mathrm{CD}^{+} 2 \mathrm{C}^{+} \mathrm{T}$ cells in PBMC are shown for $2 \mathrm{C}^{+} \mathrm{RAG}^{-1-} \mathrm{I}-\mathrm{A}^{\mathrm{b}+1+}, 2 \mathrm{C}^{+} \mathrm{RAG}^{-1-} \mathrm{I-}$ $A^{b+l-}$, and $2 C^{+} R_{A G}{ }^{-1-}-A^{b-1-}$ mice. One symbol represents one mouse. The horizontal line indicates the average within each genotype.

harbored $\mathrm{CD}^{+}\left(\mathrm{CD}^{-}\right) 2 \mathrm{C}^{+} \mathrm{T}$ cells, with frequencies in individual mice ranging from $0.5 \%$ to as high as $\approx 50 \%$ (Figs. $1 B$ and $2 B$ ). The $\mathrm{CD} 4{ }^{+} 2 \mathrm{C}$ T cells were likely generated in the thymus because CD4 single-positive thymocytes were frequently detected in the thymus of $2 \mathrm{C}^{+} \mathrm{RAG}^{-1-}$ mice (Fig. $1 A$ ).

Similar to $\mathrm{CD}^{+}{ }^{+} \mathrm{T}$ cells in lymph nodes of $\mathrm{B} 6$ mice, the $\mathrm{CD}^{+} 2 \mathrm{C}$ $\mathrm{T}$ cells in $2 \mathrm{C}^{+} \mathrm{RAG}^{-/-}$mice exhibited a naïve phenotype as indicated by the expression patterns of CD44, CD25, CD122, CD11a, and Ly6C (Fig. 1C). However, different from CD4 ${ }^{+}$T cells in $\mathrm{B} 6$ mice, which were $\mathrm{CD} 45 \mathrm{RB}^{\mathrm{hi}}$ and $\mathrm{HSA}^{\mathrm{lo}}$, the $\mathrm{CD} 4^{+} 2 \mathrm{C}$ T cells in $2 \mathrm{C}^{+} \mathrm{RAG}^{-1-}$ mice were CD45RB ${ }^{\mathrm{lo}}$ and $\mathrm{HSA}^{\mathrm{hi}}$, resembling the phenotype of CD4 single-positive thymocytes (Fig. $1 C$ and data not shown). Whether these differences are significant or merely the result of comparing a monoclonal population of $\mathrm{T}$ cells in $2 \mathrm{C}^{+} \mathrm{RAG}^{-1-}$ mice with a polyclonal population of $\mathrm{T}$ cells in $\mathrm{B} 6$ mice is not clear. It is clear, however, that the $\mathrm{CD}^{+}{ }^{+} 2 \mathrm{C}$ T cells in the lymph nodes of $2 \mathrm{C}^{+} \mathrm{RAG}^{-/-}$mice were not short-lived, immature $\mathrm{T}$ cells that somehow managed to migrate into the periphery; thus, when adoptively transferred into nonirradiated syngeneic $\mathrm{RAG} 1^{-1-}$ mice, the $\mathrm{CD} 4^{+} 2 \mathrm{C}$ T cells persisted in the recipients for months and acquired a memory-like CD $44^{\text {hi }}, \mathrm{CD}_{45 \mathrm{RB}}{ }^{\mathrm{lo}}, \mathrm{CD} 122^{+}$, and $\mathrm{Ly}_{6 \mathrm{C}} \mathrm{C}^{\mathrm{lo}}$ phenotype, similar to transferred $\mathrm{CD} 8^{+} 2 \mathrm{C}$ T cells (Fig. $1 B$ and $C$ and data not shown), indicating that they can undergo lymphopenia-induced development $(33,34)$. Together, these findings show that mature $\mathrm{CD}^{+}{ }^{+} \mathrm{C}$ T cells can develop in $\mathrm{RAG}^{-/-}$ mice that express a single $2 \mathrm{C} \mathrm{TCR}$ known to be restricted by $\mathrm{MHC}$ class I.

Development of $\mathrm{CD4}^{+}$2C T Cells Requires both MHC Class I and II Molecules. The development of $\mathrm{CD}^{+} 2 \mathrm{C}$ T cells in $2 \mathrm{C}^{+} \mathrm{RAG}^{-1-}$ mice raises the question of whether these $\mathrm{T}$ cells are positively selected by MHC class I or class II molecules or both. To answer the question, we generated $2 \mathrm{C}^{+} \mathrm{RAG}^{-1-}$ mice on an $\mathrm{I}-\mathrm{A}^{\mathrm{b}+/+}$, $\mathrm{I}-\mathrm{A}^{\mathrm{b}+1-}$, or $\mathrm{I}-\mathrm{A}^{\mathrm{b}-1-}$ background. Because B6 mice are naturally defective in I-E $\alpha$ expression, $2 \mathrm{C}^{+} \mathrm{RAG}^{-1-} \mathrm{I}-\mathrm{A}^{\mathrm{b}-1-}$ mice are defi- 

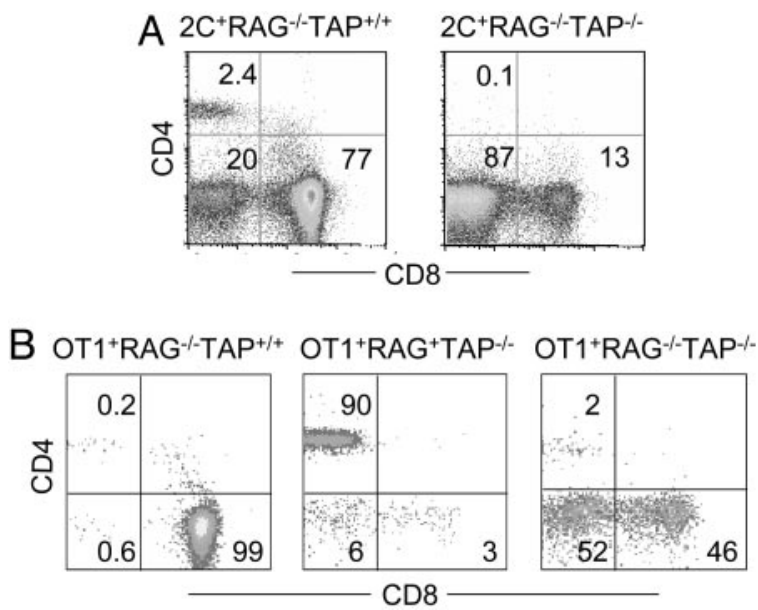

Fig. 3. Development of $\mathrm{CD} 4^{+} \mathrm{T}$ cells in $2 \mathrm{C}^{+} \mathrm{RAG}^{-1-}$ mice $(A)$ and $\mathrm{OT}-1^{+} \mathrm{RAG}^{-1-}$ mice $(B)$. (A) PBMC from $2 \mathrm{C}^{+} \mathrm{RAG}^{-l-} \mathrm{TAP}^{+/+}$and $2 \mathrm{C}^{+} \mathrm{RAG}^{-l-} \mathrm{TAP}^{-1-}$ mice were analyzed for $2 \mathrm{CTCR}, \mathrm{CD} 4$, and $\mathrm{CD} 8$ expression. $C D 4$ versus $\mathrm{CD} 8$ expression profiles are shown for $2 \mathrm{C}^{+} \mathrm{T}$ cells. (B) PBMC of OT-1+RAG ${ }^{-1-} \mathrm{TAP}^{+/+}$, OT$1^{+} \mathrm{RAG}^{+} \mathrm{TAP}^{-1-}$, and $\mathrm{OT}-1^{+} \mathrm{RAG}^{-/-} \mathrm{TAP}^{-/-}$mice were stained with anti-V $\alpha 2$, anti-CD4, and anti-CD8. CD4 versus CD8 expression profiles are shown for $\mathrm{V} \alpha 2^{+} \mathrm{T}$ cells. The numbers indicate the percentages of $\mathrm{T}$ cells in the specific quadrants. Data from representative mice are shown.

cient in MHC class II molecules, except for a low level of I-A $\alpha / \mathrm{I}-\mathrm{E} \beta$ heterodimer (35). As shown in Fig. 2, $\mathrm{CD}^{+} 2 \mathrm{C} \mathrm{T}$ cells were undetectable in the peripheral blood of $2 \mathrm{C}^{+} \mathrm{RAG}^{-/-} \mathrm{I}-\mathrm{A}^{\mathrm{b}-/-}$ mice, whereas they were readily detected and at the similar frequencies in $2 \mathrm{C}^{+} \mathrm{RAG}^{-1-}$ mice on either the $\mathrm{I}-\mathrm{A}^{\mathrm{b}+/+}$ or the $\mathrm{I}-\mathrm{A}^{\mathrm{b}+/-}$ background. Thus, the development of $\mathrm{CD}^{+} 2 \mathrm{C} \mathrm{T}$ cells requires positive selection mediated by the $\mathrm{MHC}$ class II I- $\mathrm{A}^{\mathrm{b}}$ molecule, indicating that the $2 \mathrm{C}$ TCR interacts directly with $\mathrm{I}^{\mathrm{b}} \mathrm{A}^{\mathrm{b}}$ [likely associated with peptide(s)].

To test the requirement for $\mathrm{MHC}$ class I molecules in the development of $\mathrm{CD}^{+} 2 \mathrm{C}$ T cells, we generated $2 \mathrm{C}^{+} \mathrm{RAG}^{-1-}$ mice on a TAP $^{-1-}$ background. As expected, the number and percentage of $\mathrm{CD}^{+} 2 \mathrm{C}$ T cells were greatly reduced in $2 \mathrm{C}^{+} \mathrm{RAG}^{-1-} \mathrm{TAP}^{-1-}$ mice (Fig. $3 A$ and data not shown). Despite the normal expression of $\mathrm{I}_{-} \mathrm{A}^{\mathrm{b}}$ in $2 \mathrm{C}^{+} \mathrm{RAG}^{-1-} \mathrm{TAP}^{-/-}$mice (data not shown), almost no $\mathrm{CD}^{+}{ }^{+} \mathrm{C}$ T cells were detected in 20 mice analyzed; most of the $2 \mathrm{C}$ $\mathrm{T}$ cells in these mice were $\mathrm{CD}^{-} \mathrm{CD}^{-}$. The absence of $\mathrm{CD}^{+}{ }^{+} \mathrm{C}$ $\mathrm{T}$ cells in $2 \mathrm{C}^{+} \mathrm{RAG}^{-1-} \mathrm{TAP}^{-/-}$mice suggests that the development of $\mathrm{CD} 4^{+} 2 \mathrm{C} \mathrm{T}$ cells requires positive selection by both $\mathrm{MHC}$ class I and II molecules.

Development of $\mathbf{C D 4}^{+} \mathbf{2} \mathbf{C}$ T Cells in $\mathbf{2} \mathbf{C}^{+} \mathbf{R A G}+$ Mice. Whereas there were no detectable $\mathrm{CD}^{+}{ }^{+} \mathrm{C}$ T cells in $2 \mathrm{C}^{+} \mathrm{RAG}^{-1-} \mathrm{TAP}^{-1-}$ mice, in $2 \mathrm{C}^{+} \mathrm{RAG}^{+} \mathrm{TAP}^{-1-}$ mice most of the $2 \mathrm{C}^{+} \mathrm{T}$ cells were $\mathrm{CD}^{+}$and only a small fraction was either $\mathrm{CD}^{+}$or $\mathrm{CD}^{-} \mathrm{CD}^{-}$(Fig. 4A). Among the three $2 \mathrm{C}^{+}$fractions, the $2 \mathrm{C}^{+} \mathrm{CD} 8^{+}$and the $2 \mathrm{C}^{+} \mathrm{CD}^{-} \mathrm{CD}^{-} \mathrm{T}$ cells expressed a uniformly high level of the $2 \mathrm{C}$ $\mathrm{TCR}$, whereas the $2 \mathrm{C}^{+} \mathrm{CD} 4^{+} \mathrm{T}$ cells expressed a lower level of the $2 \mathrm{C}$ TCR, and the expression pattern was broad (Fig. 4A). In addition, $2 \mathrm{C}^{+} \mathrm{RAG}^{+} \mathrm{TAP}^{-/-}$mice contained a significant fraction of $\mathrm{CD}^{+}$cells that did not express the $2 \mathrm{C} \mathrm{TCR}$. The $2 \mathrm{C}^{-} \mathrm{CD} 4^{+}$cells are likely $\mathrm{CD} 4^{+} \mathrm{T}$ cells that express endogenous TCR $\alpha$ chains along with the transgenic $2 \mathrm{C} \mathrm{TCR} \beta$ chain so that the resulting TCRs are not reactive with the clonotypic antibody (1B2). Both $2 \mathrm{C}^{+} \mathrm{CD} 4{ }^{+}$ and $2 \mathrm{C}^{-} \mathrm{CD}^{+} \mathrm{T}$ cells exhibited a naïve phenotype as indicated by their CD $44^{\text {lo }}, \mathrm{CD} 25^{-}$, and CD45RB ${ }^{\text {hi }}$ expression profiles (Fig. $4 B$ ). $2 \mathrm{C}^{+} \mathrm{CD} 4^{-} \mathrm{T}$ cells, which consisted of $2 \mathrm{C}^{+} \mathrm{CD}^{+}$and $2 \mathrm{C}^{+} \mathrm{CD} 4^{-} \mathrm{CD}^{-}$cells, were more heterogenous in expression of CD44 and CD45RB. These results show that large numbers of
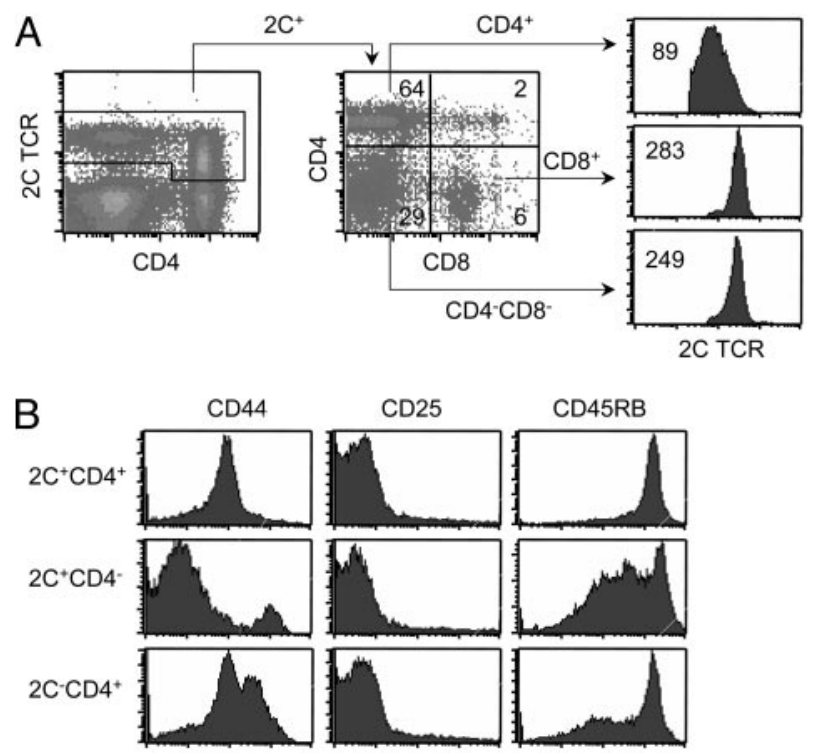

Fig. 4. Surface phenotype of $C D 4^{+} 2 \mathrm{C}$ T cells in $2 \mathrm{C}^{+} \mathrm{RAG}^{+} \mathrm{TAP}^{-1-}$ mice. $(A)$ Lymph node cells of $2 \mathrm{C}^{+} \mathrm{RAG}^{+} \mathrm{TAP}^{-1-}$ mice were analyzed for $2 \mathrm{CTCR}, \mathrm{CD} 4$, and CD8. (Left) 2 C TCR versus CD4 staining profile of all live cells. (Center) CD4 versus $\mathrm{CD} 8$ expression profile gating on $2 \mathrm{C}^{+} \mathrm{T}$ cells. (Right) Comparison of $2 \mathrm{C}$ $\mathrm{TCR}$ levels among $2 \mathrm{C}^{+} \mathrm{CD} 4^{+}, 2 \mathrm{C}^{+} \mathrm{CD} 8^{+}$, and $2 \mathrm{C}^{+} \mathrm{CD} 4^{-} \mathrm{CD} 8^{-} \mathrm{T}$ cells. Data from one representative mouse are shown. (B) Lymph node cells of $2 \mathrm{C}^{+} \mathrm{RAG}^{+} \mathrm{TAP}^{-1-}$ mice were analyzed for $2 \mathrm{C}$ TCR, CD4, plus CD44, CD25, or CD45RB. The expression of CD44, CD25, and CD45RB is shown for $2 \mathrm{C}^{+} \mathrm{CD}^{+}, 2 \mathrm{C}^{+} \mathrm{CD} 4^{-}$, and $2 \mathrm{C}^{-} \mathrm{CD}^{+} \mathrm{T}$ cells.

mature $\mathrm{CD}^{+} 2 \mathrm{C}$ T cells can be generated in $2 \mathrm{C}^{+} \mathrm{RAG}^{+} \mathrm{TAP}^{-/-}$ mice.

To examine their functional properties, $\mathrm{CD}^{+} 2 \mathrm{C} \mathrm{T}$ cells were purified from $2 \mathrm{C}^{+} \mathrm{RAG}^{+} \mathrm{TAP}^{-1-}$ mice by cell sorting and then stimulated weekly with irradiated splenocytes from $\beta 2$-microglobu$\mathrm{lin}^{-1-}$ mice in the presence of cytokines. In culture, the $\mathrm{CD}^{+} 2 \mathrm{C}$ $\mathrm{T}$ cells proliferated slowly but established a CD4 ${ }^{+} 2 \mathrm{C} \mathrm{T}$ cell line. CTL activity of the CD4 ${ }^{+} 2 \mathrm{C} \mathrm{T}$ cell line was compared with that of a CD8 ${ }^{+} 2 \mathrm{C}$ T cell clone, L3.100, by using SIY-labeled T2- $\mathrm{K}^{\mathrm{b}}$ target cells in a 6 -h ${ }^{51} \mathrm{Cr}$-release assay. As expected, L3.100 cells lysed SIY-pulsed T2- $\mathrm{K}^{\mathrm{b}}$ target cells effectively: At an effector-to-target cell ratio (E:T ratio) of 10:1 and SIY at $0.1 \mu \mathrm{M}, 85 \%$ of target cells were lysed (Fig. $5 A$ ). In contrast, the $\mathrm{CD}^{+}{ }^{+} 2 \mathrm{C} \mathrm{T}$ cell line did not significantly lyse SIY-labeled $\mathrm{T} 2-\mathrm{K}^{\mathrm{b}}$ targets cells, even at an E:T ratio of 50:1 and a SIY concentration of $1 \mu \mathrm{M}$, indicating that either the $\mathrm{CD}^{+} 2 \mathrm{C} \mathrm{T}$ cell line did not possess much cytolytic activity and/or coreceptor CD8 is required for lysis of the $\mathrm{T} 2-\mathrm{K}^{\mathrm{b}}$ target cells.

To distinguish between the two possibilities, QL9-labeled T2- $\mathrm{L}^{\mathrm{d}}$ cells were used as target cells because the QL9- $\mathrm{L}^{\mathrm{d}}$ complex can activate the $2 \mathrm{C}$ TCR independent of CD8, in contrast to SIY-K ${ }^{\mathrm{b}}$, which requires $\mathrm{CD} 8$ coreceptor to activate $2 \mathrm{C}$ T cells (9). As shown in Fig. 5A, L3.100 cells lysed QL9-pulsed T2- $\mathrm{L}^{\mathrm{d}}$ target cells extremely effectively; i.e., lysis remained at a near maximal level $(\approx 85 \%)$ at an E:T ratio of 10:1 and $0.01 \mu \mathrm{M} \mathrm{QL9}$ peptide. Although the $\mathrm{CD}^{+}{ }^{+} \mathrm{C}$ T cell line exhibited significant lysis of QL9-labeled T2- $\mathrm{L}^{\mathrm{d}}$ target cells, its cytolytic activity was far lower than that of the L3.100 clone: Even at an E:T ratio of 50:1 and $1 \mu \mathrm{M}$ QL9 peptide, there was only $\approx 27 \%$ target cell lysis (Fig. $5 A$ ). Thus, the CD $4^{+} 2 \mathrm{C}$ $\mathrm{T}$ cell line exhibited little cytolytic activity and resembled $\mathrm{CD} 4^{+} \mathrm{T}$ cells in general.

Expression of Two TCRs by CD4 ${ }^{+} \mathbf{2 C}$ T Cells in $\mathbf{2 C ^ { + }}$ RAG $^{+}$Mice. Because the development of $\mathrm{CD}^{+} 2 \mathrm{C}$ T cells in $2 \mathrm{C}^{+} \mathrm{RAG}^{-/-}$mice requires the presence of both MHC class I and II molecules, it was surprising 

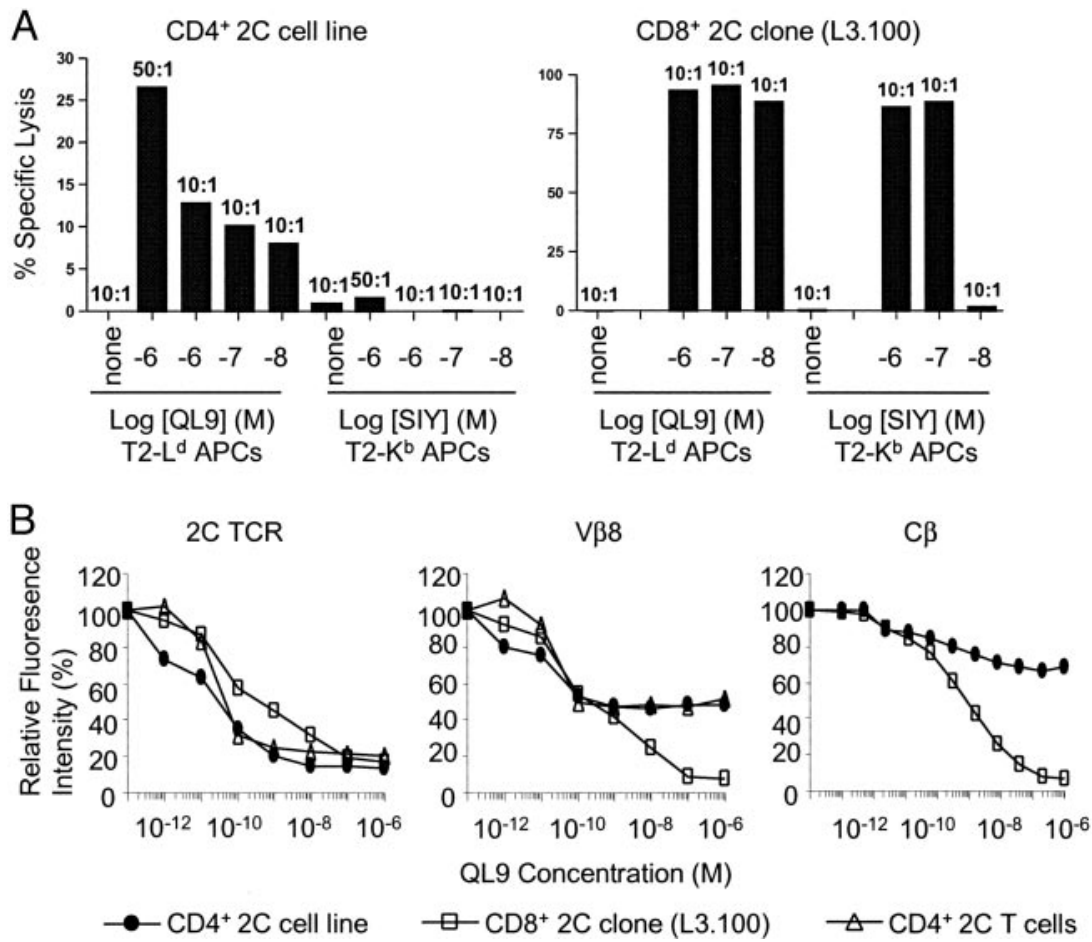

Fig. 5. $C D 4^{+} 2 C$ T cells respond to allogeneic QL9- $L^{d}$ but not to syngeneic SIY-Kb stimulations. (A) Comparison of cytolytic activities between a CD4 ${ }^{+} 2 C T$ cell line and a CD8 ${ }^{+} 2$ C CTL clone (L3.100). See Materials and Methods for details. The ratios indicate E:T ratios. Percentages of specific lysis are shown. (B) Comparison of TCR down-regulation in the CD4 ${ }^{+} 2 \mathrm{C} \mathrm{T}$ cell line, the CD8 ${ }^{+} 2 \mathrm{C}$ clone L3.100, and the freshly isolated CD4 ${ }^{+} 2 \mathrm{C} \mathrm{T}$ cells in response to QL9- $\mathrm{L}^{\mathrm{d}}$ stimulation. CD4 ${ }^{+}$ $2 \mathrm{C}$ T cells from $2 \mathrm{C}^{+} \mathrm{RAG}^{+} \mathrm{TAP}^{-1-}$ mice (triangle) or from the cultured $\mathrm{CD} 4^{+} 2 \mathrm{C}$ line (circle) and the $\mathrm{L} 3.100$ cells (square) were incubated with $\mathrm{T} 2-\mathrm{L}^{\mathrm{d}}$ cells in the presence of the indicated concentrations of QL9 peptide at $37^{\circ} \mathrm{C}$ overnight. The cells were then stained for the $2 \mathrm{C}$ TCR (1B2), anti-V $\beta 8$, or anti-C $\beta$ antibodies. Fluorescence intensities of $2 \mathrm{CTCR}, \mathrm{V} \beta 8$, and $\mathrm{C} \beta$ on the three types of T cells without QL9 stimulation are arbitrarily defined as $100 \%$, and fluorescence intensities of treated samples are normalized to that of the untreated samples. The relative fluorescence intensities of $2 \mathrm{CTCR}, \mathrm{V} \beta 8$, and C $\beta$ are shown as a function of QL9 peptide concentrations for the three cell types.

that large numbers of $\mathrm{CD}^{+}{ }^{+} \mathrm{C} \mathrm{T}$ cells were generated in $2 \mathrm{C}^{+} \mathrm{RAG}^{+} \mathrm{TAP}^{-1-}$ mice. Because endogenous TCR $\alpha$ genes can be rearranged in $2 \mathrm{C}^{+} \mathrm{RAG}^{+} \mathrm{TAP}^{-1-}$ but not in $2 \mathrm{C}^{+} \mathrm{RAG}^{-1-} \mathrm{TAP}^{-1-}$ mice, $\mathrm{CD}^{+} 2 \mathrm{C} \mathrm{T}$ cells generated in $2 \mathrm{C}^{+} \mathrm{RAG}^{+} \mathrm{TAP}^{-/-}$mice probably express additional TCRs, which likely promote CD4 lineage development. Consistent with this hypothesis, $\mathrm{CD} 4^{+} 2 \mathrm{C} \mathrm{T}$ cells expressed much lower levels of $2 \mathrm{C} \mathrm{TCR}$ than did $\mathrm{CD}^{+}$or $\mathrm{CD} 4^{-} \mathrm{CD}^{-}{ }^{-} \mathrm{C}$ T cells in the same $2 \mathrm{C}^{+} \mathrm{RAG}^{+} \mathrm{TAP}^{-1-}$ mice (Fig. $4 A$ ). To further test this hypothesis, we compared the extent of TCR down-regulation in the $\mathrm{CD} 4^{+} 2 \mathrm{C} \mathrm{T}$ cell line and the $\mathrm{CD} 8^{+} 2 \mathrm{C}$ clone L3.100 after TCR ligation. To minimize a requirement for CD8, T cells were cultured overnight in the presence of $\mathrm{T} 2-\mathrm{L}^{\mathrm{d}}$ cells plus various amounts of the QL9 peptide, and the levels of $2 \mathrm{C}$ TCR, total TCR, and $\mathrm{V} \beta 8$ (used by $2 \mathrm{C} \mathrm{TCR} \beta$ ) were measured by flow cytometry by using antibodies specific for the $2 \mathrm{C}$ TCR, $\mathrm{C} \beta$, and $\mathrm{V} \beta 8$, respectively. When measured with the $1 \mathrm{~B} 2$ antibody, specific for the $2 \mathrm{C}$ TCR, both the $\mathrm{CD}^{+}{ }^{+} 2 \mathrm{C} \mathrm{T}$ cell line and $\mathrm{L} 3.100$ clone exhibited a QL9 dosage-dependent down-regulation of the 2C TCR (Fig. 5B Left). Importantly, the extent of 2C TCR down-regulation was the same and nearly complete for both cell types.

Similarly, when measured with antibodies specific for the $\mathrm{C} \beta$ or the $\mathrm{V} \beta 8$, both the $\mathrm{CD} 4{ }^{+} 2 \mathrm{C} \mathrm{T}$ cell line and $\mathrm{L} 3.100$ clone exhibited a QL9 dosage-dependent TCR down-regulation. However, whereas the TCR down-regulation was nearly complete with L3.100 cells, it was only $\approx 50 \%$ or less with the CD ${ }^{+} 2 \mathrm{C}$ T cell line (Fig. $5 B$ Center and Right). To exclude any possible artifact due to the use of a cell line, we performed the same assay with freshly isolated CD4 ${ }^{+} 2 \mathrm{C}$ $\mathrm{T}$ cells from spleen and lymph nodes of $2 \mathrm{C}^{+} \mathrm{RAG}^{+} \mathrm{TAP}^{-1-}$ mice. Down-regulation of the $2 \mathrm{C}$ TCR on primary CD4 ${ }^{+} 2 \mathrm{C}$ T cells was QL9 dosage-dependent and nearly complete when measured with 1B2 antibody (Fig. 5B Left), whereas TCR down-regulation was $\approx 50 \%$ when measured with anti-V $\beta 8$. Together, these results strongly suggest that $\mathrm{CD}^{+}{ }^{+} \mathrm{C}$ T cells in $2 \mathrm{C}^{+} \mathrm{RAG}^{+} \mathrm{TAP}^{-/-}$mice express other TCRs in addition to the 2C TCR. Based on the incomplete down-regulation of $\mathrm{V} \beta 8$, the other TCRs likely consist of the transgenic TCR $\beta$ and endogenous TCR $\alpha$ chains and do not interact with the QL9- $\mathrm{L}^{\mathrm{d}}$ complexes.

Development of CD4 ${ }^{+}$T Cells in 0T-1 TCR-Transgenic Mice. To extend the generality of the observations with the 2C TCR, we analyzed T cell development in transgenic mice expressing the OT-1 TCR in the absence of RAG1 and/or TAP (on the H-2 background). As with the 2C TCR, the OT-1 TCR is positively selected by MHC class $\mathrm{I} \mathrm{K}^{\mathrm{b}}$. Because there is no antibody specific for the OT-1 TCR, the OT-1 T cells were identified by anti-V $\alpha 2$ antibody specific for the OT- 1 TCR $\alpha$ chain. In $>50$ OT $-1^{+} \mathrm{RAG}^{-/-} \mathrm{TAP}^{+/+}$mice analyzed, almost all $\mathrm{V} \alpha 2^{+} \mathrm{T}$ cells were $\mathrm{CD} 8^{+}$and only very few were $\mathrm{CD}^{+}$ or $\mathrm{CD}^{-} \mathrm{CD}^{-}$(Fig. $3 B$ ). However, in two OT- $1^{+} \mathrm{RAG}^{-1-} \mathrm{TAP}^{-/-}$ mice analyzed, of the $\mathrm{V} \alpha 2^{+} \mathrm{T}$ cell population a large fraction were still $\mathrm{CD} 8^{+}$, but the majority were $\mathrm{CD} 4^{-} \mathrm{CD} 8^{-}$, and a significantly higher percentage were $\mathrm{CD}^{+}$than in $\mathrm{OT}-1^{+} \mathrm{RAG}^{-1-} \mathrm{TAP}^{+/+}$ mice $(2 \%$ versus $0.2 \%$ ). Therefore, in the absence of TAP and positive selection mediated by $\mathrm{K}^{\mathrm{b}}$, the OT- 1 TCR probably has an increased probability of interacting with MHC class II, thereby leading to thymocyte differentiation into $\mathrm{CD}^{+} \mathrm{T}$ cells. Most dramatically, $\approx 90 \%$ of $\mathrm{V} \alpha 2^{+}$T cells in $\mathrm{OT}-1^{+} \mathrm{RAG}^{+} \mathrm{TAP}^{-/-}$mice were $\mathrm{CD}^{+}$(Fig. 3B). The OT- 1 TCR $\beta$ chain has been shown to pair with $\mathrm{TCR} \alpha$ chains that differ only in the CDR3 region to generate both $\mathrm{CD}^{+}$and $\mathrm{CD}^{+} \mathrm{T}$ cells in mice $(36,37)$. Thus, rearrangement of endogenous TCR $\alpha$ genes in OT$1^{+} \mathrm{RAG}^{+} \mathrm{TAP}^{-/-}$mice and expression of TCRs consisting of OT-1 TCR $\beta$ and endogenous TCR $\alpha$ chains, in addition to the OT- 1 TCR, 
likely have promoted the observed development of CD4 T cells in the absence of TAP.

\section{Discussion}

The 2C TCR Recognizes both Class I and Class II MHC Molecules. The 2C TCR has been shown to recognize syngeneic MHC class I $\mathrm{K}^{\mathrm{b}}$ $(16,17,19)$, allogeneic $\mathrm{L}^{\mathrm{d}}$ and $\mathrm{K}^{\mathrm{bm} 3}(10,12-15)$, and a yet-to-be identified nonclassical class I molecule (20). In this report, we show that the $2 \mathrm{C}$ TCR also recognizes the MHC class II I-A ${ }^{\mathrm{b}}$ for the development of $\mathrm{CD}^{+}{ }^{+} 2 \mathrm{C}$ T cells (Figs. 1 and 2). Similarly, the development of $\mathrm{CD}^{+} \mathrm{OT}-1 \mathrm{~T}$ cells in $\mathrm{OT}-1^{+} \mathrm{RAG}^{-1-} \mathrm{TAP}^{-1-}$ mice suggests that the OT-1 TCR also interacts with I-A ${ }^{\text {b }}$ (Fig. $3 B$ ). Thus, like AND, HA, and HY TCRs (21-23), the 2C and OT-1 TCRs recognize peptides presented by both class I and class II MHC molecules. To determine whether these TCRs are unusual, we reviewed the literature for $\mathrm{T}$ cell development in TCRtransgenic mice that have been crossed onto the $\mathrm{RAG}^{-/-}$background. Among $24 \mathrm{TCR} / \mathrm{RAG}$ transgenic lines that we found, both $\mathrm{CD}^{+}$and $\mathrm{CD}^{+}{ }^{+}$single-positive $\mathrm{T}$ cells were reported in the thymus and/or peripheral lymph organs in 22 lines (Table 1, which is published as supporting information on the PNAS web site). In most of these transgenic lines development of $\mathrm{T}$ cells was usually biased to one lineage; however, in many lines the other lineage $\mathrm{T}$ cells were as abundant or only 2- to 3-fold fewer. Although the minor selecting MHC molecules have not been identified for most of these TCRs, these observations strengthen the view that the individual TCR can recognize diverse MHC molecules.

Recent studies suggest that, when only a limited set of self-pMHC complexes is available in the thymus for positive selection, the TCRs of the selected mature $\mathrm{T}$ cells are especially degenerate and tend to recognize both $\mathrm{MHC}$ class I and MHC class II as well as multiple foreign (allogeneic) MHC $(38,39)$. The $2 \mathrm{C} \mathrm{TCR}$ arose in a BALB.B $\left(\mathrm{H} 2^{\mathrm{b}}\right)$ mouse $(10,11)$. It is possible that in the BALB.B environment the set of self-peptides that binds to $\mathrm{K}^{\mathrm{b}}$ is not entirely congruent with the set that binds to $\mathrm{K}^{\mathrm{b}}$ in the $\mathrm{B} 6$ environment, but it is not obvious that the peptide $-\mathrm{K}^{\mathrm{b}}$ set in the BALB.B thymus would be unusually constricted. Moreover, the well known prevalence of allogeneic reactivity seen in polyclonal antivirus and other $\mathrm{T}$ cell responses $(40,41)$ suggests that the extensive reactivity of $2 \mathrm{C}$ TCR with diverse MHC molecules is not unusual. This feature is likely quite common based on the extremely high percentage of TCRs that are capable of promoting both $\mathrm{CD} 4^{+}$and $\mathrm{CD}^{+} \mathrm{T}$ cell development in $\mathrm{RAG}^{-1-}$ background (Table 1). There is little evidence to suggest that a TCR should be restricted by any particular MHC molecule (42). The observed restriction by predominantly one MHC molecule for a given TCR likely arises from thymic selection with small but critical contributions of peptide(s) bound to that MHC. Taken together with the ability of a single TCR to recognize a large number of different peptides in association with the same MHC molecule (43-46), the ability of the same TCR to interact with multiple MHC molecules, including both class I and class II, reinforces the view that TCR recognition of peptide-MHC complexes can be highly degenerate.

\footnotetext{
Development of $\mathrm{CD}^{+} 2 \mathrm{C}$ T Cells Requires Positive Selection by both MHC Class I and MHC Class II Molecules. One of the functional consequences of the $2 \mathrm{C}$ TCR recognition of $\mathrm{I}-\mathrm{A}^{\mathrm{b}}$ is the development of $\mathrm{CD}^{+}{ }^{+} 2 \mathrm{C} \mathrm{T}$ cells in the thymus. A significant fraction of $2 \mathrm{C}^{+} \mathrm{RAG}^{-/-}$mice $(\approx 30 \%)$ develop $\mathrm{CD}^{+}{ }^{+} 2 \mathrm{C} \mathrm{T}$ cells, comprising $0.5-50 \%$ of total $2 \mathrm{C}$ T cells (Figs. 1 and 2 ). These CD $4^{+} 2 \mathrm{C}$ T cells are evidently positively selected by $\mathrm{I}-\mathrm{A}^{\mathrm{b}}$, because they were absent in $2 \mathrm{C}^{+} \mathrm{RAG}^{-1-} \mathrm{I}-\mathrm{A}^{\mathrm{b}-1-}$ mice. Interestingly, development of these $\mathrm{CD}^{+}{ }^{+} \mathrm{C} \mathrm{T}$ cells also requires the TAP gene because they were absent in $2 \mathrm{C}^{+} \mathrm{RAG}^{-/-} \mathrm{TAP}^{-/-}$mice (Fig. $3 A$ ). In the absence of TAP, the levels of class I expression on the cell surface are dramatically reduced, impairing both TCR-class I and CD8-class I interactions. Although it is formally possible that CD8 and class I MHC molecules have to interact in order for CD4 $\mathrm{T}$ cells to
}

develop, the absence of $\mathrm{CD}^{+} 2 \mathrm{C}$ T cells in $2 \mathrm{C}^{+} \mathrm{RAG}^{-1-} \mathrm{TAP}^{-1-}$ mice most likely results from the reduced interaction between the 2C TCR and the class I MHC $\left(\mathrm{K}^{\mathrm{b}}\right)$ molecule.

The requirement of both class I and class II MHC for the development of $\mathrm{CD}^{+}{ }^{+} 2 \mathrm{C} \mathrm{T}$ cells resembles the development of $\mathrm{CD}^{+} \mathrm{T}$ cells in transgenic mice expressing the nominally $\mathrm{MHC}$ class II-restricted HA and AND TCRs $(22,23)$. The difference is that, in case of the $2 \mathrm{C} \mathrm{TCR}$, most $2 \mathrm{C} \mathrm{T}$ cells generated in the $\mathrm{RAG}^{-1-}$ background are $\mathrm{CD} 8^{+}$, and the development of $\mathrm{CD} 4^{+} 2 \mathrm{C}$ $\mathrm{T}$ cells requires positive selection by not only class II (I-A $\left.{ }^{\mathrm{b}}\right)$ but also class I. In the case of HA and AND TCRs, most T cells generated in the $\mathrm{RAG}^{-1-}$ or $\mathrm{CD} 4^{-1-}$ and TCR $\alpha^{-1-}$ background are $\mathrm{CD} 4^{+}$, and the development of $\mathrm{CD}^{+} \mathrm{T}$ cells requires not only MHC class I but also MHC class II.

How is CD4 versus CD8 lineage commitment accomplished if both class I and class II MHC molecules are involved in positive selection? Although the precise mechanisms underlying the development of CD4 versus CD8 lineage T cells are still controversial, interactions among TCRs, coreceptors, and self-pMHC are critical for the outcome $(4,5,7)$. Recent studies suggest that the duration of TCR signaling may control CD4 versus CD8 lineage differentiation (47). According to the kinetic signaling model (48), upon the initial interaction among TCR, coreceptors, and pMHC, DP thymocytes down-regulate CD8 to become CD4 ${ }^{+} \mathrm{CD} 8^{\text {lo }}$ cells (49). Transient TCR signaling in $\mathrm{CD} 4^{+} \mathrm{CD} 8{ }^{\text {lo }}$ cells results in $\mathrm{CD} 8$ lineage differentiation, and persistent TCR signaling in $\mathrm{CD} 4^{+} \mathrm{CD} 8^{\text {lo }}$ cells results in CD4 lineage differentiation (47). The requirement of both class I and class II MHC for the development of $\mathrm{CD}^{+} 2 \mathrm{C}$ T cells from a nominally class I-restricted TCR is consistent with this model. Perhaps 2C TCR interaction with some pMHC class II complexes, in addition to its interaction with pMHC class I complexes, might provide the sustained TCR signaling in $\mathrm{CD}^{+}{ }^{+} \mathrm{CD} 8^{\text {lo }}$ cells required for $\mathrm{CD}^{+}{ }^{+} 2 \mathrm{C} \mathrm{T}$ cell development. However, this model does not explain the requirement of both class I and class II MHC for the development of $\mathrm{CD}^{+} \mathrm{HA}$ and AND T cells from these nominally class II-restricted TCRs.

Our findings in $2 \mathrm{C}^{+} \mathrm{RAG}^{-/-}$mice appear to provide a clue to this conundrum. In $2 \mathrm{C}^{+} \mathrm{RAG}^{-/-}$mice, only a fraction of $\mathrm{T}$ cells develop into $\mathrm{CD}^{+} 2 \mathrm{C}$ T cells $(0.5-50 \%)$, and only a fraction of the mice harbor the $\mathrm{CD}^{+}{ }^{+} \mathrm{C}$ T cells $(\approx 30 \%)$. Similarly, in the HA and AND TCR-transgenic $\left(\mathrm{RAG}^{-1-}\right.$ or TCR $\left.\alpha^{-/-}\right)$mice, only a fraction of T cells are $\mathrm{CD}^{+}$, and the percentages of mice developing $\mathrm{CD} 8^{+} \mathrm{T}$ cells were not reported $(22,23)$. The variation among mice could result from background differences, although the $2 \mathrm{C}^{+} \mathrm{RAG}^{-1-}$ mice have been backcrossed onto the B6 background for 13 generations. That only a fraction of $2 \mathrm{C} \mathrm{T}$ cells are $\mathrm{CD}^{+}$in $2 \mathrm{C}^{+} \mathrm{RAG}^{-1-}$ mice suggests that not all developing DP thymocytes have equal access to $\mathrm{I}-\mathrm{A}^{\mathrm{b}}$. Variability in the pMHC complexes available at a given time or location in the thymus likely affects a thymocyte's development into a CD4 or CD8 T cell (50). Thus, when, where, and how long TCR, coreceptors, and self-pMHC interact probably has a significant effect on CD4 versus CD8 lineage differentiation.

Development of $\mathrm{CD}^{+} 2 \mathrm{C}$ T Cells as a Consequence of Expression of Additional TCR. In the 2C TCR-transgenic mice on the $\mathrm{RAG}^{+}$ background, large numbers of $\mathrm{CD}^{+}{ }^{+} 2 \mathrm{C}^{+} \mathrm{T}$ cells are generated (Fig. 4), consistent with a previous report (51). Two lines of evidence suggest that, because of the lack of TCR $\alpha$ allelic exclusion $(25,28)$, these T cells express two different TCRs. First, although the level of total TCR among $\mathrm{CD}^{+}, \mathrm{CD}^{+}$, and $\mathrm{CD} 4^{-} \mathrm{CD} 8^{-} 2 \mathrm{C}$ $\mathrm{T}$ cells was similar, the $\mathrm{CD} 4^{+} 2 \mathrm{C}$ T cells had a lower level of the $2 \mathrm{C}$ TCR than did the other $2 \mathrm{C}$ T cells (Figs. 4 and 5 and data not shown), similar to other transgenic $\mathrm{T}$ cells that express two TCRs (52). Second, after QL9- $\mathrm{L}^{\mathrm{d}}$ stimulation the 2C TCR was almost as completely down-regulated from $\mathrm{CD}^{+}{ }^{+} 2 \mathrm{C}$ T cells (as from $\mathrm{CD}^{+}$ $2 \mathrm{C}$ T cells), but $50 \%$ of the TCR persisted when assayed with anti-C $\beta$ or anti-V $\beta 8$ antibodies (Fig. 5). The $2 \mathrm{C}$ TCR $\beta$ utilizes the 
$\mathrm{V} \beta 8$ gene segment (16), and the fact that the persistent TCRs still react with anti-V $\beta 8$ (Fig. 5) suggests that the second TCR is composed of the transgenic TCR $\beta$ and an endogenous $\operatorname{TCR} \alpha$ chain. Some of these nontransgenic TCRs expressed on $2 \mathrm{C} \mathrm{T}$ cells are likely positively selected by class II I- $\mathrm{A}^{\mathrm{b}}$ molecules and therefore promote the development of $\mathrm{CD}^{+}{ }^{+} \mathrm{T}$ cells. However, the precise nature of the $2 \mathrm{C}$ TCR-class I MHC interaction that contributes to the development of $\mathrm{CD}^{+} \mathrm{T}$ cells in $2 \mathrm{C}^{+} \mathrm{RAG}^{+}$mice is unclear.

The same mechanisms likely underlie the development of large numbers of $\mathrm{CD}^{+}{ }^{+} \mathrm{OT}-1 \mathrm{~T}$ cells in OT- $1^{+} \mathrm{RAG}^{+} \mathrm{TAP}^{-/-}$mice (Fig. $3 B$ ), especially because the OT- 1 TCR $\beta$ chain is known to pair with different TCR $\alpha$ chains to generate both $\mathrm{CD} 4^{+}$and $\mathrm{CD}^{+} \mathrm{T}$ cells $(36,37)$. Unlike these previous observations, however, the $\mathrm{CD}^{+}$ OT-1 $\mathrm{T}$ cells in $\mathrm{OT}-1^{+} \mathrm{RAG}^{+} \mathrm{TAP}^{-1-}$ mice likely express two TCRs: one consisting of the transgenic TCR $\beta$ and transgenic TCR $\alpha$ chains and the other consisting of the transgenic TCR $\beta$ and endogenous TCR $\alpha$ chains. In humans, $\approx 20 \%$ of $\mathrm{T}$ cells are estimated to express two TCRs, and in mice $\approx 10 \%$ of T cells express two TCRs (30). Thus, the effect of expressing two TCRs in the same developing thymocyte could significantly affect its ultimate development into a CD4 or CD8 T cell.

\section{Materials and Methods}

Mice and Cell Lines. 2C TCR-transgenic mice on either the $\mathrm{RAG}^{-/-}$or RAG1 ${ }^{+}$background were backcrossed onto C57BL/6 background for 13 generations (33). Similarly, OT-1 TCRtransgenic mice on either the RAG1 ${ }^{-1-}$ or $\mathrm{RAG} 1^{+}$background were backcrossed onto the B6 background for 10 generations. B6 mice and B6 mice deficient in I-A ${ }^{\mathrm{b}}$, TAP, or $\beta 2$-microglobulin were purchased from The Jackson Laboratory. RAG1 ${ }^{-/-}$mice, backcrossed with B6 mice for 13 generations, were used as adoptive transfer recipients. All mice were kept under specific pathogen-free facilities and used between 6 and 12 weeks of age. L3.100 is a CD8 ${ }^{+}$ CTL clone from a 2 C TCR-transgenic mouse. T2- $\mathrm{L}^{\mathrm{d}}$ and $\mathrm{T} 2-\mathrm{K}^{\mathrm{b}}$ cell lines are human B cell lymphoma T2 cells stably expressing the mouse $\mathrm{L}^{\mathrm{d}}$ or $\mathrm{K}^{\mathrm{b}}$ gene, respectively.

1. Davis, M. M., Boniface, J. J., Reich, Z., Lyons, D., Hampl, J., Arden, B. \& Chien, Y. (1998) Annu. Rev. Immunol. 16, 523-544.

2. Goldrath, A. W. \& Bevan, M. J. (1999) Nature 402, 255-261.

3. Rudolph, M. G., Luz, J. G. \& Wilson, I. A. (2002) Annu. Rev. Biophys. Biomol. Struct. 31, 121-149.

4. von Boehmer, H. (1994) Cell 76, 219-228.

5. Starr, T. K., Jameson, S. C. \& Hogquist, K. A. (2003) Annu. Rev. Immunol. 21, 139-176.

6. von Boehmer, H. (2004) Adv. Immunol. 84, 201-238.

7. Singer, A. \& Bosselut, R. (2004) Adv. Immunol. 83, 91-131.

8. Robey, E. \& Fowlkes, B. J. (1994) Annu. Rev. Immunol. 12, 675-705.

9. Chen, J., Eisen, H. N. \& Kranz, D. M. (2003) Microbes Infect. 5, 233-240.

10. Kranz, D. M., Sherman, D. H., Sitkovsky, M. V., Pasternack, M. S. \& Eisen, H. N. (1984) Proc. Natl. Acad. Sci. USA 81, 573-577.

11. Saito, H., Kranz, D. M., Takagaki, Y., Hayday, A. C., Eisen, H. N. \& Tonegawa, S. (1984) Nature 309, 757-762.

12. Udaka, K., Tsomides, T. J. \& Eisen, H. N. (1992) Cell 69, 989-998.

13. Udaka, K., Tsomides, T. J., Walden, P., Fukusen, N. \& Eisen, H. N. (1993) Proc. Natl. Acad. Sci. USA 90, 11271-11276.

14. Tallquist, M. D. \& Pease, L. R. (1995) J. Immunol. 155, 2419-2426.

15. Sha, W. C., Nelson, C. A., Newberry, R. D., Pullen, J. K., Pease, L. R., Russell, J. H. \& Loh, D. Y. (1990) Proc. Natl. Acad. Sci. USA 87, 6186-6190.

16. Sha, W. C., Nelson, C. A., Newberry, R. D., Kranz, D. M., Russell, J. H. \& Loh, D. Y. (1988) Nature 335, 271-274.

17. Sha, W. C., Nelson, C. A., Newberry, R. D., Kranz, D. M., Russell, J. H. \& Loh, D. Y. (1988) Nature 336, 73-76.

18. Dutz, J. P., Tsomides, T. J., Kageyama, S., Rasmussen, M. H. \& Eisen, H. N. (1996) Mol. Immunol. 31, 967-975.

19. Udaka, K., Wiesmuller, K. H., Kienle, S., Jung, G. \& Walden, P. (1996) J. Immunol. 157, 670-678.

20. Maurice, M. M., Gould, D. S., Carroll, J., Vugmeister, Y. \& Ploegh, H. L. (2001) Proc. Natl. Acad. Sci. USA 98, 7437-7442.

21. Arsov, I. \& Vukmanovic, S. (1999) J. Immunol. 162, 2008-2015.

22. Kirberg, J., Baron, A., Jakob, S., Rolink, A., Karjalainen, K. \& von Boehmer, H. (1994) J. Exp. Med. 180, 25-34.

23. Matechak, E. O., Killeen, N., Hedrick, S. M. \& Fowlkes, B. J. (1996) Immunity 4, 337-347.
Antibodies and Flow Cytometry Analysis. Antibodies to CD8, CD25, CD44, CD11a, CD45RB, HSA, CD28, Ly-6C, CD122, V $\beta 8$, and $\mathrm{TCR} \beta(\mathrm{C} \beta)$ were purchased as conjugates from BD Pharmingen. Clonotypic antibody $1 \mathrm{~B} 2$, specific for the $2 \mathrm{C}$ TCR, was conjugated to biotin. Single-cell suspensions were prepared from thymus, lymph nodes, spleen, and peripheral blood mononuclear cells (PBMC). Red blood cells were lysed by treating splenocytes and PBMC with lysis buffer. Cells were stained in the presence of 2.5 $\mu \mathrm{g} / \mathrm{ml}$ anti-FcR antibody in PBS containing $0.1 \%$ BSA and $0.1 \%$ $\mathrm{NaN}_{3}$ and analyzed on a FACSCalibur. Analyses were carried out with CELLQUEST software.

Establishment of a CD4 ${ }^{+} 2 \mathrm{C}$ T Cell Line, T Cell Activation Assay, and CTL Assay. $\mathrm{CD}^{+}{ }^{+} \mathrm{C}$ T cells were isolated from lymph nodes and spleen of $2 \mathrm{C}^{+} \mathrm{RAG}^{+} \mathrm{TAP}^{-/-}$mice by cell sorting. The cells were then stimulated weekly with irradiated splenocytes from $\beta 2$-microglobu$\mathrm{lin}^{-/-}$mice in the presence of supernatants of Con A-stimulated rat splenocytes (a source of cytokines). To assay $\mathrm{T}$ cell activation, the resulting $\mathrm{CD}^{+} 2 \mathrm{C} \mathrm{T}$ cell line and a $\mathrm{CD} 8^{+} 2 \mathrm{C} \mathrm{CTL}$ clone were cultured at $\approx 5 \times 10^{5}$ cells per $\mathrm{ml}$ at $37^{\circ} \mathrm{C}$ in the presence of QL9 peptide-loaded T2- $\mathrm{L}^{\mathrm{d}}$ cells. Twenty-four hours later, the levels of TCR on $2 \mathrm{C} \mathrm{T}$ cells were measured by staining with antibodies specific for the $2 \mathrm{C} \mathrm{TCR}, \mathrm{V} \beta 8$, or TCR $\beta$. For CTL assays, the CD $4^{+}$ 2C T cell line or L3.100 clone were incubated for $6 \mathrm{~h}$ with ${ }^{51} \mathrm{Cr}$-labeled $\mathrm{T} 2-\mathrm{L}^{\mathrm{d}}$ target cells in the presence of various concentrations of the QL9 peptide or with ${ }^{51} \mathrm{Cr}$-labeled T2-K $\mathrm{K}^{\mathrm{b}}$ target cells in the presence of various concentrations of the SIY peptide. Specific lysis was calculated as [(experimental counts - spontaneous counts)/(total counts - spontaneous counts)] $\times 100$.

We thank Carol McKinley for technical support and members of the J.C. laboratory for advice, comments, and review of the manuscript. This work was supported in part by National Institutes of Health Grants AI50631 and AI40146 (to J.C.) and CA60686 (to H.N.E.) and Core Grant CA140451 to the Massachusetts Institute of Technology Center for Cancer Research (to Tyler Jacks).

24. Sleckman, B. P., Gorman, J. R. \& Alt, F. W. (1996) Annu. Rev. Immunol. 14, 459-481. 25. von Boehmer, H. (1990) Annu. Rev. Immunol. 8, 531-556.

26. Casanova, J.-L., Romero, P., Widmann, C., Kourilsky, P. \& Maryanski, J. L. (1991) J. Exp. Med. 174, 1371-1373.

27. Lacorazza, H. D. \& Nikolich-Zugich, J. (2004) J. Immunol. 173, 5591-5600.

28. Gascoigne, N. R. \& Alam, S. M. (1999) Semin. Immunol. 11, 337-347.

29. Borgulya, P., Kishi, H., Uematsu, Y. \& von Boehmer, H. (1992) Cell 69, 529-537.

30. Padovan, E. G., Casorati, P., Dellabona, P., Meyer, S., Brockhaus, M. \& Lanzavecchia, A. (1993) Science 262, 422-424.

31. Gladow, M., Uckert, W. \& Blankenstein, T. (2004) Eur. J. Immunol. 34, 1882-1891.

32. Robertson, J. M. \& Evavold, B. D. (1999) J. Immunol. 163, 1750-1754.

33. Cho, B., Varada, R., Ge, Q., Eisen, H. E. \& Chen, J. (2000) J. Exp. Med. 192, 549-556.

34. Jameson, S. C. (2002) Nat. Rev. Immunol. 2, 547-556.

35. Martin, B., Bourgeois, C., Dautigny, N. \& Lucas, B. (2003) Proc. Natl. Acad. Sci. USA 100, 6021-6026.

36. Correia-Neves, M., Waltzinger, C., Mathis, D. \& Benoist, C. (2001) Immunity 14, 21-32.

37. Correia-Neves, M., Mathis, D. \& Benoist, C. (2001) Eur. J. Immunol. 31, 2583-2592.

38. Logunova, N. N., Viret, C., Pobezinsky, L. A., Miller, S. A., Kazansky, D. B., Sundberg, J. P. \& Chervonsky, A. V. (2005) J. Exp. Med. 202, 73-84.

39. Huseby, E. S., White, J., Crawford, F., Vass, T., Becker, D., Pinilla, C., Marrack, P. \& Kappler, J. W. (2005) Cell 122, 247-260.

40. Nahill, S. R. \& Welsh, R. M. (1993) J. Exp. Med. 177, 317-327.

41. Lindahl, K. F. \& Wilson, D. B. (1977) J. Exp. Med. 145, 507-522.

42. Zerrahn, J., Held, W. \& Raulet, D. H. (1997) Cell 88, 627-636.

43. Malissen, B. (2003) Immunity 19, 463-464.

44. Wucherpfennig, K. W. (2004) Mol. Immunol. 40, 1009-1017.

45. Cohn, M. (2005) Mol. Immunol. 42, 1419-1443.

46. Eisen, H. N., Sykulev, Y. \& Tsomides, T. J. (1996) Adv. Protein Chem. 49, 1-56.

47. Liu, X. \& Bosselut, R. (2004) Nat. Immunol. 5, 280-288.

48. Bosselut, R. (2004) Nat. Rev. Immunol. 4, 529-540.

49. Brugnera, E., Bhandoola, A., Cibotti, R., Yu, Q., Guinter, T. I., Yamashita, Y., Sharrow, S. O. \& Singer, A. (2000) Immunity 13, 59-71.

50. Canelles, M., Park, M. L., Schwartz, O. M. \& Fowlkes, B. J. (2003) Nat. Immunol. 4, 756-764.

51. Chen, F.-L. \& Kung, J. T. (1996) J. Immunol. 156, 2036-2044

52. Heath, W. R. \& Miller, J. F. (1993) J. Exp. Med. 178, 1807-1811. 